\title{
Analisis Kontribusi Pajak Hiburan Terhadap Pendapatan Asli Daerah (PAD) Kota Palembang
}

\author{
Rendi Wijaya \\ Akuntansi, STIE ABDI NUSA Palembang \\ rendiwijaya50@yahoo.com
}

\begin{abstract}
ABSTRAK
Penelitian ini bertujuan untuk mengetahui besarnya kontribusi Pajak Hiburan terhadap Pajak Daerah dan Pendapatan Asli Daerah (PAD) Kota Palembang, naik turunnya Penerimaan Pajak Hiburan serta efektivitas Pajak hiburan di Kota Palembang pada tahun 2016 sampai dengan tahun 2018.Jenis pada Penelitian ini adalah Studi Kasus. Teknik Pengumpulan data yang digunakan adalah wawancara dan dokumentasi, untuk menjawab permasalahan digunakan analisis kontribusi yaitu dengan cara membandingkan Pajak Hiburan terhadap Pendapatan Asli Daerah (PAD) dikalikan $100 \%$ dan membandingkan Pajak Hiburan terhadap Pajak Daerah dikalikan 100\%. Sedangkan untuk mengetahui efektivitas Pajak Hiburan yaitu dengan cara membandingkan realisasi Pajak Hiburan dengan target Pajak Hiburan dikalikan $100 \%$. Hasil penelitian menunjukkan bahwa berdasarkan hasil analisis data dan pembahasan yang telah dilakukan di Kota Palembang menunjukkan masih kurangnya kontribusi Pajak Hiburan terhadap Pajak Daerah maupun Pendapatan Asli Daerah (PAD) walaupun efektivitas Pajak Hiburan Selalu Melebihi dari terget yang ditetapkan.
\end{abstract}

Kata Kunci : Pajak Hiburan, Pajak Daerah, dan Pendapatan Asli Daerah (PAD)

\section{A. PENDAHULUAN}

Undang-Undang No.33 Tahun 2004 tentang perimbangan keuangan antara pemerintah pusat dan pemerintah daerah pasal 1 ayat 18 menyebutkan bahwa, PAD adalah pendapatan yang diperoleh daerah yang dipungut berdasarkan peraturan daerah. Sumber PAD terdiri dari pajak daerah, restribusi daerah, laba dari Badan Usaha Milik Daerah (BUMD), dan pendapatan asli daerah lainnya yang sah. Pajak daerah yang merupakan salah satu sumber PAD memiliki peranan cukup besar. Pendapatan pajak daerah yang tinggi sangat membantu daerah otonom untuk merealisasikan pembangunan daerah. Pajak daerah diatur dalam Undang-Undang No. 28 Tahun 2009 tentang Pajak Daerah dan Retribusi Daerah sebagaimana telah diubah beberapa kali atas Undang-Undang No.34 Tahun 2000 dan UndangUndang No.18 Tahun 1997. Pajak daerah memiliki berbagai potensi untuk menjadi sumber penerimaan daerah, salah satu potensi tersebut adalah pajak hiburan.

Dalam Undang-Undang No 28 Tahun 2009 terdapat berbagai jenis pajak daerah, dan salah satunya adalah pajak hiburan. Palembang termasuk dalam daerah otonom. Program pembangunan daerah yang dirancangkan pemerintah memerlukan tersedianya dana yang besar. Dana ini disamping diperoleh dari bantuan pemerintah pusat, sebagian diperoleh dari usaha pemerintah daerah sendiri. Palembang juga tergantung pada sektor pariwisata. Salah satu penunjang pariwisata kota Palembang adalah tersedianya berbagai fasilitas hiburan yang memadai, seperti bioskop, diskotik, klab malam, bar, karaoke, billiard, panti pijat, refleksi, dan wisata air. Tersedianya bermacam-macam fasilitas hiburan semakin memanjakan para wisatawan yang datang berkunjung menikmati indahnya kota Palembango, bahkan 
masyarakat Palembang pun turut mengambil bagian dalam mempergunakan fasilitas hiburan yang ada. Semakin tinggi minat konsumen terhadap fasilitas hiburan maka, semakin tinggi pula pajak yang dipungut atas penggunaan hiburan tersebut. Hal ini sangat menguntungkan bagi pemerintah kota Palembang, karena pajak yang dipungut dapat meningkatkan PAD guna membantu pemerintah melaksanakan program pembangunan, mensejahterakan daerah, serta pembiayaan program kerja pemerintah daerah lainnya.

Pajak daerah memiliki berbagai potensi untuk menjadi sumber penerimaan daerah, salah satu potensi tersebut adalah pajak hiburan. Potensi pajak hiburan merupakan salah satu sumber dari penerimaan pajak daerah di Kota Palembang. Pajak hiburan memiliki peran yang cukup besar terhadap pendapatan asli daerah. Secara umum, jika potensi pajak hiburan semakin banyak maka pendapatan daerah yang diterima akan meningkat dan kontribusi pajak terhadap pendapatan asli daerah berpengaruh signifikan. Pajak hiburan di Kota Palembang memiliki realisasi penerimaan yang setiap tahunnya meningkat dan target penerimaan pajak hiburan tidak terpenuhi. Pertumbuhan pajak hiburan diharapkan dapat ditingkatkan sehingga kontribusi pajak hiburan dapat mendapatkan hasil yang optimal. Potensi yang ada di Kota Palembang khususnya sektor pajak hiburan agar di manfaatkan secara optimal. Bagi Badan Pengelolaan Pajak Daerah (BPPD) Kota Palembang diupayakan agar selalu melakukan pendekatan kepada wajib pajak. Karena pentingnya pajak bagi suatu pemerintah daerah, pajak menjadi faktor krusial bagi suatu daerah untuk membangun daerahnya sendiri.

Berdasarkan Latar Belakang tersebut diatas, maka judul penelitian ini adalah "Analisis Kontribusi Pajak Hiburan terhadap Pendapatan Asli Daerah (PAD) Kota Palembang".

\section{B. KAJIAN PUSTAKA Pajak}

Soemitro dalam Gunawan (2011) menyatakan, pajak adalah iuran rakyat kepada kas Negara berdasarkan Undang - undang (yang dapat dipaksakan) dengan tiada mendapat jasa timbal (kontra prestasi) yang langsung dapat ditunjukkan dan yang digunakan untuk membayar pengeluaran umum. Smeets dalam Pakakhid (2011) mengemukakan pengertian pajak, yaitu prestasi kepada pemerintah yang terutang melalui norma-norma umum, dan yang dapat di paksakan, tanpa adakalanya kontraprestasi yang dapat ditujukan dalam hal yang individual.

\section{Fungsi Pajak}

Pajak memiliki fungsi yang sangat strategis bagi berlangsungnya pembangunan suatu negara. Fungsi pajak diantaranta adalah fungsi anggaran (budgetair), fungsi mengatur (regulerend), fungsi stabilitas, fungsi redistribusi pendapatan.

\section{Jenis - Jenis Pajak}

Jenis-jenis pajak dapat dikelompokkan sebagai berikut.

1. Pengelompokkan pajak menurut golongannya, yaitu pajak langsung dan pajak tidak langsung.

2. Pengelompokan pajak menurut sifatnya, yaitu pajak subyektif dan pajak obyektif

3. Pengelompokan pajak menurut lembaga pemungutnya, yaitu pajak pusat (pajak negara) dan pajak daerah. 


\section{Pajak Daerah}

Marsyahrul dalam Dewangga (2012) menyatakan, pajak daerah adalah pajak yang di kelolah oleh pemerintah daerah (baik pemerintah daerah TK.I maupun pemerintah daerah TK.II) dan hasil di pergunakan untuk membiayai pengeluaran rutin dan pembangunan daerah (APBD).

\section{Jenis-jenis Pajak Daerah}

1. Jenis pajak provinsi terdiri atas, pajak kendaraan bermotor, bea balik nama kendaraan bermotor, pajak bahan bakar kendaraan bermotor, pajak air permukaan dan pajak rokok.

2. Jenis pajak kabupaten/kota terdiri atas, pajak hotel, pajak restoran, pajak hiburan, pajak reklame, pajak penerangan jalan, pajak parkir, pajak mineral bukan logam dan batuan, pajak air tanah, pajak sarang burung wallet, PBB pedesaan dan perkotaan, dan bea perolehan hak atas tanah dan bangunan.

\section{Sistem Pemungutan Pajak Daerah}

Ketentuan yang diatur dalam UndangUndang Ketentuan Umum dan Tata Cara Perpajakan Indonesia dengan jelas menentukan bahwa sistem perpajakan Indonesia adalah self assessment. Hal ini telah diberlakukan sejak reformasi perpajakan di Indonesia tahun 1983. Penetapan system self assessment juga dianut dalam Undang-Undang Nomor 18 Tahun 1997 dan Undang-undang Nomor 34 Tahun 2000. Karena karakteristik setiap jenis pajak daerah tidak sama, sistem ini tidak dapat diberlakukan untuk semua jenis pajak daerah. Pemungutan pajak daerah saat ini menggunakan tiga sistem pemungutan pajak, yaitu:

1. dibayar sendiri oleh wajib pajak. Sistem ini merupakan perwujudan dari sistem self assessment.

2. Ditetapkan oleh kepala daerah. Sistem ini merupakan perwujudan dari sistem official

3. Dipungut oleh pemungut pajak. Sistem ini merupakan perwujudan dari sistem with holding.

Secara umum, sistem yang digunakan dalam pemunguan pajak daerah, baik sistem self assessment dan official assessment. Tergantung pada jenis pajak.

\section{Pajak Hiburan}

Sesuai dengan Undang-Undang Nomor 28 Tahun 2009 Pasal 1 angka 24 dan 25, Pajak Hiburan adalah pajak atas penyelenggaraan hiburan. Sedangkan yang dimaksud dengan hiburan adalah semua jenis tontonan, pertunjukan, permainan, dan atau keramaian yang dinikmati dengan dipungut bayaran.

\section{Dasar Hukum Pemungutan Pajak Hiburan}

Dasar hukum pemungutan Pajak Hiburan pada suatu kabupaten atau kota adalah, Undang-Undang Nomor 28 tahun 2009 tentang Pajak Daerah dan Retribusi Daerah, Undang-Undang No. 34 Tahun 2000, yang merupakan perubahan atas Undang- Undang No. 18 Tahun 1997 tentang Pajak Daerah dan Retribusi Daerah, Peraturan Pemerintah Nomor 65 Tahun 2001 tentang Pajak Daerah, Peraturan daerah kabupaten / kota yang mengatur tentang Pajak Hiburan, dan Keputusan bupati / walikota yang mengatur tentang Pajak Hiburan sebagai aturan pelaksana peraturan daerah tentang Pajak Hiburan pada kabupaten / kota dimaksud.

\section{Subjek dan Objek Pajak Hiburan}

Undang-Undang No 28 tahun 2009 tentang pajak daerah dan retribusi 
daerah Pasal 43, menyebutkan subjek pajak hiburan yaitu sebagai berikut :

1. Subjek pajak hiburan adalah orang pribadi atau badan yang menikmati hiburan.

2. Wajib pajak hiburan adalah orang pribadi atau badan yang menyelenggarakan hiburan.

Undang-Undang No 28 tahun 2009 tentang pajak dan retribusi daerah Pasal 4,2 disebutkan sebagai berikut:

1. Objek pajak hiburan adalah jasa penyelenggaraan hiburan dengan dipungut bayaran.

2. Hiburan tersebut sebagaimana dimaksud pada ayat (1) adalah, tontonan filmpagelaran kesenian, musik, tari, dan/atau busanakontes kecantikan, binaraga, dan sejenisnyapamerandiskotik,

karaoke, klab malam, dan sejenisnyasirkus, akrobat, dan sulappermainan bilyar, golf, dan bolingpacuan kuda, kendaraan bermotor, dan permainan ketangkasanpanti pijat, refleksi, mandi uap/spa, dan pusat kebugaran (fitness center); dan pertandingan olahraga

3. Penyelenggaraan hiburan sebagaimana dimaksud pada ayat (2) dapat dikecualikan dengan peraturan daerah

\section{Masa Pajak, Tahun Pajak, saat Terutang Pajak, dan Wilayah Pemungutan Pajak hiburan.}

Pada pajak hiburan, masa pajak merupakan jangka waktu yang lamanya sama dengan satu bulan takwim atau jangka waktu lain yang dditetapkan dengan keputusan bupati/walikota. Dalam pengertian masa pajak bagian dari bulan dihitung satu bulan penuh. Tahun pajak adalah jangka waktu yang lamanya satu tahun takwim, kecuali apabila wajib pajak menggunakan tahun buku yang tidak sama dengan tahun takwim. Penetapan jangka waktu lain selain satu bulan takwim sebagai masa pajak.

Pajak yang terutang merupakan pajak hiburan yang harus dibayar oleh wajib pajak pada suatu saat, dalam masa pajak, atau dalam tahun pajak menurut ketentuan peraturan daerah tentang pajak hiburan yang ditetapkan oleh pemerintah daerah kabupaten/kota setempat. Saat pajak terutang dalam masa pajak terjadi pada saat penyelenggaraan hiburan. Jika pembayaran diterima penyelenggara hiburan sebelum hiburan diselenggarakan, pajak hiburan terutang dalam masa pajak terjadi pada saat pembayaran.

Pajak hiburan yang terutang dipungut di wilayah kabupaten/kota tempat hiburan diselenggarakan. Hal ini terkait dengan kewenangan pemerintah kabupaten/kota yang hanya terbatas atas setiap tempat hiburan yang berlokasi dan terdaftar dalam lingkup wilayah administrasinya.

Tabel 1. Kriteria Nilai Kontribusi Pajak Hiburan terhadap Pajak Daerah

\begin{tabular}{|c|c|}
\hline Persentase Kontribusi & Kriteria \\
\hline $0-10 \%$ & Sangat Kurang \\
\hline $10,10 \%-20 \%$ & Kurang \\
\hline $20,10 \%-30 \%$ & Cukup \\
\hline $30,10 \%-40 \%$ & Sedang \\
\hline $40,10 \%-50 \%$ & Baik \\
\hline$>50 \%$ & Sangat Baik \\
\hline
\end{tabular}

Sumber : Tim Litbang Depdagri Fisipol UGM, 1991 (dalam Yulia Anggara Sari, 2011) 
Untuk menjawab seberapa besar kontribusi Pajak hiburan terhadap $\frac{\text { penerimaan pajak hiburan }}{\text { penerimaan pajak daerah }} \times 100 \%$

Pajak Daerah di Kota Palembang tahun 2016 - 2018 dengan menggunakan rumus :

Tabel 2. Kriteria Nilai Kontribusi Pajak Hiburan terhadap PAD

\begin{tabular}{|c|c|}
\hline Persentase Kontribusi & Kriteria \\
\hline $0-10 \%$ & Sangat Kurang \\
\hline $10,10 \%-20 \%$ & Kurang \\
\hline $20,10 \%-30 \%$ & Cukup \\
\hline $30,10 \%-40 \%$ & Sedang \\
\hline $40,10 \%-50 \%$ & Baik \\
\hline$>50 \%$ & Sangat Baik \\
\hline
\end{tabular}

Sumber : Tim Litbang Depdagri Fisipol UGM, 1991 (dalam Yulia Anggara Sari, 2011)

Untuk menjawab seberapa besar kontribusi Pajak hiburan terhadap Pendapatan Asli Daerah (PAD) di Kota
Palembang tahun 2016 - 2018 dengan menggunakan rumus :

Tabel 3. Kriteria Efektivitas Pajak Hiburan

\begin{tabular}{|c|c|}
\hline Persentase Kontribusi & Kriteria \\
\hline Diatas $100 \%$ & Sangat Efektif \\
\hline $90 \%-100 \%$ & Efektif \\
\hline $80 \%-90 \%$ & Cukup Efektif \\
\hline $60 \%-80 \%$ & Kurang Efektif \\
\hline Kurang dari $60 \%$ & Tidak Efektif \\
\hline Sumber : Tim Litbang Depdagri Fisipol UGM, 1991 (dalam Yulia Anggara Sari, 2011)
\end{tabular}

Untuk menjawab seberapa besar Efektivitas Pajak hiburan di Kota Palembang tahun 2016 - 2018 dengan menggunakan rumus :

$\frac{\text { realisasi penerimaan pajak hiburan }}{\text { target penerimaan pajak hiburan }} \times 100 \%$

\section{METODE PENELITIAN} Jenis Penelitian

Jenis Penelitian ini adalah studi kasis pada Badan Pengelolaan Pajak Daerah (BPPD) Kota Palembang. Studi kasus adalah penelitian yang dilakukan terhadap objek tertentu dengan mengumpulkan data yang berkaitan dan hasil penelitian serta kesimpulan hanya berlaku pada objek tertentu (Adi, 2012:26)

\section{Sumber Data}

Data yang digunakan dalam penelitian ini adalah data primer dan data sekunder. Menurut Sunyoto (2003) data primer adalah data asli yang dikumpulkan sendiri oleh peneliti untuk menjawab masalah penelitiannya secara khusus. Umumnya data primer ini sebelumnya belum tersedia, sehingga seorang peneliti harus melakukan pengumpulan sendiri data ini berdasarkan kebutuhannya seperti wawancara mendalam dengan pihak-pihak yang terkait. sedangkan data sekunder merupakan sumber data yang diperoleh secara tidak langsung atau melalui media perantara. Data sekunder dapat berupa bukti, catatan 
atau laporan historis dalam arsip (Indriantoro, 2002)

\section{TEKNIK PENGUMPULAN DATA}

Untuk memperoleh data penelitian, ada beberapa metode pengumpulan data yang digunakan dalam penelitian ini, yaitu sebagai berikut :

1. Wawancara

Wawancara adalah komunikasi dua arah untuk mendapatkan data dari responden (Hartono, 2013). Metode ini dilakukan untuk mendapatkan informasi berupa data-data atau laporan realisasi yang berhubungan dengan pajak hiburan, Pajak Daerah dan Pendapatan Asli Daerah (PAD) Kota Palembang.
2. Dokumentasi

Dokumentasi

adalah teknik pengumpulan data dengan cara mencatat data dari laporan yang dimiliki. Metode ini dilakukan untuk memperoleh data laporan realisasi pajak hiburan, Pajak Daerah, dan Pendapatan ASli Daerah Kota Palembang.

\section{E. TEKNIK ANALISIS DATA}

Metode yang dilakukan dalam penelitian ini adalah analisis deskriptif kuantitatif yaitu metode yang dilakukan dengan mengumpulkan, mengklasifikasi, menganalisis, serta menginterprestasikan data sehingga memberikan keterangan yang lengkap bagi pemecahan masalah dalam penelitian.

\section{F. HASIL PENELITIAN}

Tabel 4. Realisasi Penerimaan Pajak Hiburan tahun 2016-2018

\begin{tabular}{|c|c|}
\hline Tahun & Realisasi Penerimaan Pajak Hiburan \\
\hline 2016 & 16.940 .474 .310 \\
\hline 2017 & 22.228 .414 .984 \\
\hline 2018 & 29.632 .767 .012 \\
\hline \multicolumn{2}{|c|}{ Sumber : Badan Pengelolaan Pajak Daerah (BPPD) Kota Palembang }
\end{tabular}

Tabel 5. Target Penerimaan Pajak Hiburan tahun 2016-2018

\begin{tabular}{|c|c|}
\hline Tahun & Target Penerimaan Pajak Hiburan \\
\hline 2016 & 15.815 .739 .168 \\
\hline 2017 & 18.521 .245 .000 \\
\hline 2018 & 24.000 .000 .000 \\
\hline
\end{tabular}

Sumber : Badan Pengelolaan Pajak Daerah (BPPD) Kota Palembang

Tabel 6. Penerimaan Pajak Daerah tahun 2016-2018

\begin{tabular}{|c|c|}
\hline Tahun & Penerimaan Pajak Daerah \\
\hline 2016 & 526.867 .498 .665 \\
\hline 2017 & 602.012 .516 .072 \\
\hline 2018 & 703.685 .000 .000 \\
\hline
\end{tabular}

Sumber : Badan Pengelolaan Pajak Daerah (BPPD) Kota Palembang

Tabel 7. Penerimaan Pendapatan Asli Daerah (PAD) tahun 2016-2018

\begin{tabular}{|c|c|}
\hline Tahun & Penerimaan Pendapatan Asli Daerah (PAD) \\
\hline 2016 & 533.200 .000 .000 \\
\hline 2017 & 666.800 .000 .000 \\
\hline 2018 & 748.680 .000 .000 \\
\hline \multicolumn{2}{|c|}{ Sumber : Badan Pengelolaan Pajak Daerah (BPPD) Kota Palembang }
\end{tabular}




\section{G. PEMBAHASAN}

1. Kontribusi Pajak Hiburan terhadap Pajak Daerah :

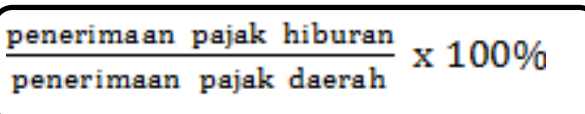

Tabel 8. Kontribusi Pajak Hiburan terhadap Pajak Daerah tahun 2016-2018

\begin{tabular}{|c|c|c|c|}
\hline Tahun & $\begin{array}{c}\text { Realisasi Penerimaan } \\
\text { Pajak Hiburan }\end{array}$ & $\begin{array}{c}\text { Penerimaan Pajak } \\
\text { Daerah }\end{array}$ & $\begin{array}{c}\text { Kontribusi } \\
(\%)\end{array}$ \\
\hline 2016 & 16.940 .474 .310 & 526.867 .498 .665 & 3,21 \\
\hline 2017 & 22.228 .414 .984 & 602.012 .516 .072 & 3,69 \\
\hline 2018 & 29.632 .767 .012 & 703.685 .000 .000 & 4,21 \\
\hline
\end{tabular}

Dari hasil tabel 8 dapat diketahui bahwa kontribusi pajak hiburan terhadap Pajak Daerah tahun 2016 sampai dengan tahun 2018 berkisar antara 3,21\% - 4,21\%. Dari tahun 2016 kontribusi pajak hiburan selalu mengalami peningkatan baik di tahun 2017 maupun di tahun 2018. Pada tahun 2017, kontribusi meningkat dari tahun sebelumnya sebesar $0,48 \%$ yaitu dari $3,21 \%$ menjadi $3,69 \%$. Sedangkan pada tahun 2018 kontribusi meningkat sebesar $0,52 \%$ yaitu dari $3,69 \%$ menjadi $4,21 \%$. Rata-rata kontribusi yang diberikan pajak hiburan terhadap pajak daerah selama tahun 2016 sampai dengan tahun 2018 adalah 3,70\%. Sedangkan kontribusi Pajak hiburan terhadap Pajak Daerah terbesar terjadi pada tahun 2018 dengan kontribusi $4,21 \%$ dan kontribusi terkecil terjadi pada tahun 2016 dengan kontribusi sebesar $3,21 \%$. Rata-rata kontribusi Pajak hiburan terhadap Pajak Daerah di Kota Palembang sebesar 3,70\%. Ini berarti Kontribusinya terhadap Pajak Daerah sangat kurang karena berada di persentase $0-10 \%$.

2. Kontribusi Pajak Hiburan terhadap PAD

$$
\frac{\text { penerimaan pajak hiburan }}{\text { penerimaan } \mathrm{PAD}} \times 100 \%
$$

Tabel 9. Kontribusi Pajak Hiburan terhadap PAD tahun 2016-2018

\begin{tabular}{|c|c|c|c|}
\hline Tahun & $\begin{array}{c}\text { Realisasi Penerimaan } \\
\text { Pajak Hiburan }\end{array}$ & Penerimaan PAD & $\begin{array}{c}\text { Kontribusi } \\
(\%)\end{array}$ \\
\hline 2016 & 16.940 .474 .310 & 533.200 .000 .000 & 3,17 \\
\hline 2017 & 22.228 .414 .984 & 666.800 .000 .000 & 3,33 \\
\hline 2018 & 29.632 .767 .012 & 748.680 .000 .000 & 3,95 \\
\hline
\end{tabular}

Dari hasil tabel 9 dapat diketahui bahwa kontribusi pajak hiburan terhadap PAD tahun 2016 sampai dengan tahun 2018 berkisar antara 3,17\% - 3,95\%. Dari tahun 2016 kontribusi pajak hiburan selalu mengalami peningkatan baik di tahun 2017 maupun di tahun 2018. Pada tahun 2017, kontribusi meningkat dari tahun sebelumnya sebesar $0,16 \%$ yaitu dari $3,17 \%$ menjadi $3,33 \%$. Sedangkan pada tahun 2018 kontribusi meningkat sebesar $0,62 \%$ yaitu dari $3,33 \%$ menjadi 3,95\%. Rata-rata kontribusi yang diberikan pajak hiburan terhadap PAD selama tahun 2016 sampai dengan tahun 2018 adalah $3,48 \%$. Sedangkan kontribusi Pajak 
hiburan terhadap PAD terbesar terjadi pada tahun 2018 dengan kontribusi $3,95 \%$ dan kontribusi terkecil terjadi pada tahun 2016 dengan kontribusi sebesar 3,17\%. Rata-rata kontribusi
Pajak hiburan terhadap Pajak Daerah di Kota Palembang sebesar 3,48\%. Ini berarti Kontribusinya terhadap Pajak Daerah sangat kurang karena berada di persentase $0-10 \%$.

3. Efektivitas Pajak Hiburan

$$
\frac{\text { realisasi penerimaan pajak hiburan }}{\text { target penerimaan pajak hiburan }} \times 100 \%
$$

Tabel 10. Efektivitas Pajak Hiburan Kota Palembang tahun 2016-2018

\begin{tabular}{|c|c|c|c|}
\hline Tahun & $\begin{array}{c}\text { Realisasi Penerimaan } \\
\text { Pajak Hiburan }\end{array}$ & $\begin{array}{c}\text { Target Penerimaan } \\
\text { Pajak Hiburan }\end{array}$ & $\begin{array}{c}\text { Efektivitas } \\
(\%)\end{array}$ \\
\hline 2016 & 16.940 .474 .310 & 15.815 .739 .168 & 107,11 \\
\hline 2017 & 22.228 .414 .984 & 18.521 .245 .000 & 120,01 \\
\hline 2018 & 29.632 .767 .012 & 24.000 .000 .000 & 123,46 \\
\hline
\end{tabular}

Dari hasil tabel 10 dapat diketahui bahwa Efektivitas Pajak Hiburan tahun 2016 sampai dengan tahun 2018 berkisar antara 107,11\% 123,46\%. Dari tahun 2016 Efektvitas pajak hiburan selalu mengalami peningkatan baik di tahun 2017 maupun di tahun 2018. Pada tahun 2017, Efektivitas meningkat dari tahun sebelumnya sebesar $12,9 \%$ yaitu dari $107,11 \% \quad$ menjadi 120,01\%. Sedangkan pada tahun 2018 Efektivitas meningkat sebesar 3,45\% yaitu dari $120,01 \%$ menjadi $123,46 \%$. Rata-rata Efektivitas pajak hiburan selama tahun 2016 sampai dengan tahun 2018 adalah 116,86\%. Sedangkan Efektivitas Pajak hiburan terbesar terjadi pada tahun 2018 sebesar $123,46 \%$ dan kontribusi terkecil terjadi pada tahun 2016 sebesar 107,11\%. Rata-rata Efektivitas Pajak hiburan sebesar $116,86 \%$. Ini menunjukkan bahwa rata-rata pendapatan pajak hiburan pada tahun 2016 - 2018 sudah sangat efektif karena ditiap tahunnya Pajak Hiburan selalu melampaui target yang ditetapkan. Akan tetapi, walaupun Pajak Hiburan sudah sangat efektif tetapi masih sangat kurang dalam kontribusinya terhadap Pajak Daerah dan Pendapatan Aset Daerah (PAD).

\section{H. KESIMPULAN DAN SARAN}

1) Kesimpulan

Penerimaan Pajak Hiburan Selama tiga tahun mulai dari tahun 2016 sampai dengan tahun 2018 terus menerus mengalami peningkatan disetiap tahunnya. Dari tabel 4 dan 5 dapat diketahui bahwa penerimaan Pajak hiburan terhadap Pajak Daerah dan Pendapatan Aset Daerah (PAD) tidak begitu besar karena kontribusi yang diberikan sangat kurang. Menurut keefektifannya, Pajak hiburan di Kota Palembang sudah Sangat Efektif karena realisasi Pajak Hiburan Selalu melebihi target yang sudah ditetapkan.

\section{2) Saran}

Pembebanan tarif pajak hiburan harus lebih diperhatikan dan diperhitungkan dengan baik, agar masyarakat yang merupakan wajib pajak hiburan tidak merasa terbebani, diharapkan kesadaran membayar pajak juga akan meningkat. Pemberian sanksi harus tepat, agar dapat memberikan efek jera kepada wajib 
pajak yang melanggar atau bertindak curang dalam pembayaran pajak.

\section{DAFTAR PUSTAKA}

Adi, Suryo Andreas. 2012. Analisis Potensi Pajak dan Retribusi Daerah. Skripsi. Yogyakarta: Sanata Dharma.

Dewangga, Jhohan. 2012. Pajak Daerah. Wordpress.com.

Gunawan, Eva, Oktavia. 2011. Definisi pajak menurut beberapa ahli. Wordpress.com.

Hartono, Jogiyanto, 2013. Metodologi Penelitian Bisnis Salah Kaprah dan Pengalaman-pengalaman. Edisi 5. BPFE-Yogyakarta

Indriantoro, Nur, Bambang Supomo. 2002. Metode Penelitian Bisnis: Untuk Akuntansi dan Manajemen. Edisi Pertama. BPFE-Yogyakarta

Mardiasmo. 2011. Perpajakan (Edisi Revisi Tahun 2011). Penerbit CV Andi Offset, Yogyakarta.
Undang-Undang No. 28 Tahun 2009, Tentang Pajak Daerah dan Retribusi Daerah sebagaimana telah diubah beberapa kali atas Undang-Undang No.34 Tahun 2000 dan Undang-Undang No.18 Tahun 1997. Jakarta.

Undang-Undang No.33 Tahun 2004, Tentang Perimbangan Keuangan Antara Pemerintah Pusat dan Pemerintah Daerah. Jakarta.

Sari, Yulia Anggara. 2011. Analisis Efektivitas dan Kontribusi Penerimaan Pajak Bumi dan Bangunan terhadap Pendapatan Daerah di Kota Bandung. Skripsi. Universitas Pendidikan Indonesia.

Utari, Tri, Utin. 2013. Analisis Sistem dan prosedur Pemungutan Pajak Hiburan pada Dinas Pendapatan Daerah Kota Pontianak. Jurnal vol.2 No.1 Universitas Tanjungpura. Pontianak. 